\title{
INTERDISCIPLINARITY IN THE PHILIPPINE ACADEMIA Theory, History, and Challenges
}

Francis C. Sollano

Ateneo de Manila University

fsollano@ateneo.edu

Jose Mari B. Cuartero

Ateneo de Manila University

jcuartero@ateneo.edu

\begin{abstract}
Forum Kritika on Interdisciplinarity in the Philippine Academia discusses the history of how universities and academics construct their respective notions of disciplinarity and interdisciplinarity. Our decision to engage with this development in tertiary education takes off from a historical phase in our educational system. Questions on the character of disciplines have heightened in the last half-century, and this phenomenon does not only emerge out of the critical practice of the people who are part of universities, but the external world of the universities have started to knock on the university doors. Informed by the present situation of our universities and the educational system at large, we both argue that both disciplinarity and interdisciplinarity are modern constructs that should be understood by elucidating dialectics of theoretical and historical underpinnings. The tandem of history and theory provides the frames for us to better see the challenges when universities implement such paradigm, and this forum hopes to shed some light to our fellow academics as the Philippines undergo crucial changes, revamps, and overhauls in our educational system.
\end{abstract}

\section{Keywords}

CMO 20, s. 2013; K to 12 system; modern university; neoliberalism; Philippine educational system 


\section{About the Authors}

Francis C. Sollano is an instructor at the Department of English, Ateneo de Manila University. His research interests include Island Studies, Filipino American Studies, Southeast Asian Literature, and Law and Literature. His recent research and publications focus on Philippine and Indonesian writers such as Nick Joaquin, Carlos Bulosan, Epifanio San Juan, Jr., and Pramoedya Ananta Toer. These works go beyond literary formalism to highlight sociocultural concerns such as subject-formation, state power, and postcolonialism.

Jose Mari Cuartero is a faculty member of the Department of English in Ateneo de Manila University. His research interests spring from the interregnum between the downfall of Spanish colonialism, and the rise of American imperialism in the Philippines. The temporal scope of his interest situates Isabelo De Los Reyes as one of the important historical actors whom he has tried to analyze, interpret, and develop arguments for the past years. However, beyond his interests in history, he has also crossed the boundaries of aesthetics, critical theory, and literature, and from these other fields of interests, one of his reviews appeared in Philippine Studies. 
The formation of this forum on interdisciplinary emerges from a climate in the Philippine academia where universities are challenged to evaluate the present curriculums. By 2014, the curriculum of the secondary education in the Philippines changed, and by adding two more years, the $\mathrm{K}$ to 12 system was implemented, causing a colossal demotion of subjects offered at the tertiary level to the secondary level. The K to 12 implementation emptied the plates of the universities in terms of their regular general curriculum offerings, and subsequently, it has also brought quite a spike in unemployment among professors in the university level as some departments were forced to downsize. Some universities, however, surfaced above the torrential flow of waves of changes, which some of them viewed as an opportunity to rethink, overhaul, and transform the landscape of higher education. With opportunities under heavens, we are both fortunate to be invited by the former editor-in-chief of the journal, Maria Luis Torres-Reyes, to formulate talking points on the matter at hand. Through the key questions, we hoped then to delineate and eventually trace a blueprint in which we could all engage intellectually and scholarly with one another as changes in higher education in the Philippines happen. The strategy we seek to respond to the political differences in the educational sector in the Philippines is by foregrounding the concept of interdisciplinarity. The idea of interdisciplinarity serves as the paradigm that allows us to rethink the impacts of the curricular changes in the secondary education and locates it conceptually as an anchoring point to a much exciting intellectual and scholarly quest for the tertiary education in the Philippines. Through the concept and theory of interdisciplinarity, we decided to spearhead a conversation among scholars in the country to share their respective ideas on interdisciplinarity and then emerging implementation of the new curriculum.

Since we have decided to foreground the concept of interdisciplinary and use it as a banner to organize our strategies in responding to the call of the times, we also recognize the challenges of the subject. When we started drafting the questions for this forum, we realize the renewed discussions on interdisciplinarity ${ }^{1}$ and how people apply it on university teaching and research, which have been both foregrounded recently. There have been debates on the topic, and these are not new. Historically, more than half a century ago, academics, coming from a variety of disciplines, have pointed out the limitations and arbitrariness of disciplinary structures. They noted the lack of collaboration and communication among "disciplinary silos" that not only fragments the educational experience of students but also impedes the growth and innovation of the disciplines themselves (Jacobs 13-26). By 1969, Muzafer Sherif and Carolyn W. Sherif, intellectual historians, jumpstarted the conversation on the nature of the intellectual disciplines, and in their efforts to lay out the terms of the discussion, they both critiqued the status quo of disciplinary practice and unraveled the extent knowledge could be richer if it operated without the conventional disciplinal boundaries. Among those who 
are in dialogue with them is Donald Campbell and he compares the disciplines to ethnocentric tribes, which is a metaphor that prevails up to this day. Campbell laments that the tendency of a discipline to concentrate on its self-made hierarchies and this behavior leaves a gaping void in various fields, which may be overlooked. ${ }^{2}$ As a result, by the turn of the twenty-first century, some have made a clarion call for "flexibility" and "adaptiveness" of different disciplines (qtd. in Graff 2). However, some still consider the disciplinary structures necessary. Many academics neither view the disciplines as neither ends in themselves nor as fixed categories. The interdisciplinary nature of disciplines has emerged for us as a development that relaxes the tight controls, regulations, and boundaries of fields of pieces of knowledge, leading a more interactive and active engagement between and among disciplines, especially at the present contemporary times.

It must be recognized, however, that pressures on the disciplinary basis of university departments have been mounting not only from inside the academia. States and industries have evolved and have possessed much power to the extent that they try to invade universities and intervene on the affairs of academic departments, allowing them to influence the substantial and operational matters in universities around the world. In 1972, the Organisation for Economic Co-operation and Development (OECD) published research entitled, Interdisciplinarity, Problems of Teaching and Research in Universities, and this is the volume Robert Frodeman hails as the "Ur-text of interdisciplinarity" for this document also coins the term "transdisciplinarity" to label an emergent practice in knowledge production which replaces the university-centered discipline-based models (Weingart 12). It was a development that disturbed academics at that time because implicit in that new mode of knowledge production was their realization of an opening of a "knowledge market," which was previously monopolized by the university, but they eventually relinquished to private think-tanks and other state and non-state agencies (Weingart 12). The rise of transdisciplinarity in the universities sent a clear message to the members of the academic community: either they shape up to prove their relevance to society, and efficiently solve real-world problems or they become wholly obsolete. The interdisciplinarity, and in its transformation, transdisciplinary, have both shaken up the stability of the universities, and perhaps, the entire educational sector. The assertion of interdisciplinarity as a paradigm for this forum also foregrounds the interventions of state politics, and even trace the new dynamics that such development creates. The state, perhaps, could be read as the new disciplinary formation that weakens the interiors of the university, and consequently, disciplines are shuffled, downsized, and worst, gradually linked to the liberal freedom of the free market society.

Since the nature of a discipline baffles us, it rationalizes the reason why interdisciplinarity continues to be a problem when people define the meaning of 
it. Julie Thompson Klein braves the amorphous character of interdisciplinarity by providing a nuanced discussion of the term through a taxonomy. The strategy of Klein unfolds through drawing out the strands that could diverge from such category, and she presents it through taxonomic classifications of fields: "multidisciplinarity," "interdisciplinarity", and "transdisciplinarity," among others. Klein also cites Lisa Lattuca, another scholar of disciplines of knowledge, and through her work, Klein proceeds by unraveling the process of integration as a "litmus test" for interdisciplinarity, and through the process of integration, multidisciplinarity only juxtaposes the disciplines (i.e. they remain separate). Interdisciplinarity, however, remains faithful to its promises as it integrates disciplinary frameworks and methods, and by allowing them to come together, methods and frameworks, they embrace one another by creating new possibilities for knowledge production (17). The possibilities one can draw from interdisciplinarity also reveals the limits of a multidisciplinary curriculum. The deceitful side of multidisciplinary occurs when it provides a buffet of courses, and by doing so, this multidisciplinarity also leaves integration as an impasse. With the temptation of covering multiple subjects and interests under multidisciplinarity, it deludes institutions for they mistake the number of subjects with institutionalizing interdisciplinarity. The broad and encyclopedic character of multidisciplinarity weakens the intensity and rigor of institutions to sustain their sense of focus, whether in teaching, scholarship, and university administration (Boden qtd. in Klein 17). The rise of "transdisciplinarity" dares to rise above the interdisciplinarity for this recent development "transcends the narrow scope of disciplinary worldviews through an overarching synthesis" (24). Across these three developments out of the concept of discipline, the interdisciplinarity continues to situate itself as the focal point from which people rethink the nature and scope of the discipline of knowledge. The promise of an intersection between and among disciplines locates a lot of scholars and academics to stand at the doorstep until this kind of synergy arrives.

Given that interdisciplinarity remains a possibility, a world to come, scholars like Joe Moran, however, celebrates the potentiality of the term. Moran recognizes the proliferation of the meaning of interdisciplinarity, and this expansion to its semantic use opens up to diverse possibilities. Moran states: "I want to suggest that the value of the term 'interdisciplinary' lies in its flexibility and indeterminacy, and that there are potentially as many forms of interdisciplinarity as there are disciplines. In a sense, to suggest otherwise would be to 'discipline' it, to confine it within a series of theoretical and methodological orthodoxies" (qtd. in Jacobs 77). Moran's statement evokes a great sense of optimism, but a closer look makes indeterminacy, and lack of consensus a delicate situation for it makes its practitioners vulnerable to the same indeterminacy and lack of consensus on the stability of their livelihood and clarity of their career futures. The "flexibility and indeterminacy" can intimidate us by its loftiness, but by unpacking its possible pretense, it only signifies vagueness 
and lack of rigor. The horrors could also escalate up to the level of implementation, and this problem may confound teachers, scholars, and administrators, leaving them with an oblique future.

Despite the fear that interdisciplinary developments can inflict on us, we can address this problem by going back to the drawing board, and we explore the nature of the disciplines again and evaluate the context in which they exist. The idea of the disciplines historically dates back to the time of the Greek Academy, and disciplines develop further in the universities during the medieval age, but its vital role has figured in our social imagination by the Second World War. The presence of internal and external pressures, such as the rise of capitalism, and the demand to win the wars all over the world, have foisted the universities to look at knowledge as a complex construction of disciplinarity which started in the nineteenth century until the Cold War years. Frodeman explains the character of the modern construction of a university through the following points: (1) "Management of knowledge through breaking materials into discrete domains," (2) "Development of a research rather than archival orientation," (3) "A premium placed on the new," and (4) "The creation of a credentialed and professionalized caste" (19-20). Frodeman's points highlight not so much the epistemological nature of the disciplines, but rather their functional and institutional basis. ${ }^{3}$ Modern disciplines certify the process of knowledge production through their validation of theoretical frameworks and research methods that professors teach to Ph.D. students. The Ph.D. graduates of their programs, in turn, perpetuate the disciplines by serving as undergraduate and graduate faculty of the same programs, as editors of peer-reviewed disciplinary journals, and as authors of research that revalidate or revaluate existing frameworks and methods, which the same professors support. The consequence manifests at the despair of academics who wrestle with the publish-or-perish culture, and this situation catalyzes this dynamic since authors' prospect to publish virtually write with their "disciplinary peers" in mind, and they are coerced to share the same language or critical vocabulary of the field.

Modern disciplines, however, dare and struggle to provide an institutional structure that can be self-regulating and self-sustaining. However, challenges persistently haunt such academic endeavor. Frodeman argues that the set of practices that used to guarantee the survival of the disciplines presently made them threatened by changes beyond the control of the universities. As a result, "transdisciplinarity" has emerged as a more sustainable response to the present university crisis $(27-28,60)$. These changes undeniably incited by the neoliberal paradigm that encroached academic institutions during the last decade of the twentieth century. The consequence of the intrusions of the neoliberal in the universities allows them to take pride in the efficiency of business models that regulate and define university policies, but progressive and leftist sectors in the 
universities condemn the rise of "academic capitalism" where the university commodifies knowledge, intellectual labor, and education at large (Fraser and Taylor 3). Such transformation of the university situate discussions of the interdisciplinarity at a very precarious situation. Any prospect of implementing and practicing interdisciplinary intellectual pursuits must contend with the neoliberal thrust of universities around the world, or else, one could be bound to fail. Universities all over the world are constrained by the current systems of metrics, accreditation, benchmarking, and ranking, among others. ${ }^{4}$ As a result, the move toward interdisciplinarity may provide an antidote to the present university crisis, which can mitigate some of the damaging effects of neoliberalism to the modern disciplinary structure..$^{5}$ Julie Klein Thompson defines the modern aspect of interdisciplinarity by showing its four major aspirations: "(1) by attempts to retain and, in many areas, reinstill historical ideas of unity and synthesis; (2) by the emergence of organized programs in research and education; (3) by the broadening of traditional disciplines; and (4) by the emergence of identifiable interdisciplinary movements" (22-23).

In the Philippines, the discussions on interdisciplinarity came to the university decades ago as well. The history of the rise of interdisciplinarity in the Philippines distinguishes Soledad S. Reyes as one of the pioneering thinkers of such intellectual development in the university. Reyes's contribution begins by assessing the trends in 1987, and she explains her notion of interdisciplinarity as "an invigorating critical enterprise [through] its openness and diversity, has yielded other meanings from traditional objects of study" (116). Reyes's efforts go beyond the limits of examples of interdisciplinarity from the West, and in her practice, what unfolds are developments in literary and cultural studies, popular culture, and theoretical movements. Reyes also recognizes a legion of practitioners apart from hers and these scholars from the Philippines articulate holistic analyses of the Philippine reality. Reyes recognizes Reynaldo Ileto, Vicente Rafael, Vicente Marasigan, Isagani Cruz, Epifanio San Juan, Jr., and Resil Mojares as some of the important names in the interdisciplinary practice in the field of Philippine Studies. However, at present, the discussions on interdisciplinarity in recent years begin as an occasion propelled by the two fundamental changes in the Philippine educational system after the implementation of the following programs in the public school system: the Enhanced Basic Education Act of 2013 (or the K to 12 Basic Education System) and the General Education Curriculum (for tertiary level education).

The Enhanced Basic Education Act of 2013 requires at least one year of kindergarten education, six years of elementary education, and six years of secondary education (Article 1, Section 4). Prior to this law, Philippine basic education did not require a year of kindergarten and had only four years of secondary education. Because of the additional two years of secondary education (or senior high school), 
the Department of Education (DepEd) was tasked to work with the Commission on Higher Education (CHED), to ensure that there is no duplication of the subjects taught in the secondary and tertiary levels (Article 1, Section 5). Some subjects and lessons previously taught in higher education institutions (HEIs) were transferred to senior high school, and these subjects comprised many of the discipline-based general education subjects in college.

Pursuant to the shift to the K to 12 system, CHED issued Memorandum Order (CMO) 20, series of 2013, which sets the guidelines for the General Education Curriculum (GEC). As stated in the CMO, the GEC "prepares the Filipino for the demands of $21^{\text {st }}$ century life and the requisite abilities to anticipate and adapt to changing situations, to think innovatively, and to create solutions to problems" (Section 1). ${ }^{6}$ The proposed GEC includes 24 units of core courses, 9 units of elective courses, and 3 units on the life and works of Rizal. The 24 units core courses (or 8 subjects) are Understanding the Self (Pag-unawa sa Sarili); Readings in Philippine History (Mga Babasahin hinggil sa Kasaysayan ng Pilipinas); The Contemporary World (Ang Kasalukuyang Daigdig); Mathematics in the Modern World (Matematika sa Makabagong Daigdig); Purposive Communication (Malayuning Komunikasyon); Art Appreciation (Pagpapahalaga sa Sining); Science, Technology and Society (Agham, Teknolohiya at Lipunan); and Ethics (Etika). It is also noted in the CMO that these courses are "inter-disciplinary and are stated broadly enough to accommodate a range of perspectives and approaches" (Section 3). ${ }^{7}$ Even the 9 units of required electives should "[a]pply an inter- or cross-disciplinary perspective" and "must cover at least any two domains of knowledge.... They may not be taken from a single domain... [to] retain the well-rounded character of General Education" (Section 4).

In 2014, Kritika Kultura organized a series of roundtable discussions to address three specific points on interdisciplinarity: its theoretical and historical underpinnings, its significance to research and creative work, and its institutional implications to the Loyola Schools (Ateneo de Manila University) curriculum and to university level curriculum in general. ${ }^{8}$ The essays in this Forum Kritika answer the concerns and questions that we prepared for the roundtable sessions. Remmon E. Barbaza's “The Bow and the Lyre: Towards a Healthy Tension between Disciplinarity and Interdisciplinarity" argues that interdisciplinarity is not antidisciplinarity-a sobering point given all the hype that interdisciplinarity has gotten in the previous decade. The external dynamism of any discipline is only possible through its internal dynamism; the balance of this tension makes for an interdisciplinarity that is done organically and through the need of the discipline itself, not through any external requirement. Maria Assunta C. Cuyegkeng's "The Context and Challenges of Interdisciplinarity in the Philippines" addresses theoretical questions on interdisciplinarity and contextualizes it within the higher 
educational system in the Philippines, highlighting the laws and memoranda that govern its implementation. The article also breaks down the complex and intertwined issues on leadership, training, and assessment of interdisciplinary practice. Michael D. Pante's "Interdisciplinarity from Below" interrogates the topdown imposition of interdisciplinarity and espouses a counter movement from the disenfranchised teachers, practitioners, and students. It asks the crucial question, "For whom is this interdisciplinarity?", and argues that if the answer to this question is not inclusive, it may just be rehashing the same problems that it sought to solve. Louie Jon A. Sánchez's "Ilang Eksplorasyon sa Pag-Aaral ng Kulturang Popular sa Filipinas" uses Philippine television soap operas (teleserye) and popular culture studies in general as ground for interdisciplinary research. It also emphasizes the localization of Cultural Studies by tracing it back to the approaches of two of the most important proponents of Filipino Studies: Jose Rizal and Isabelo delos Reyes. Taken together, these essays in this Forum Kritika partake in an interdisciplinary dialogue of scholars to theorize, problematize, and historicize the implementation of interdisciplinarity in the Philippine academia. 


\section{Notes}

1. In this essay, "interdisciplinarity" is used in a broad sense to signify "a sometimes confusing array of jargon" that surrounds the practice of collaboration and integration among the disciplines (Klein, "A Taxonomy" 15). However, this should not be mistaken to mean that the taxonomy and differences among the terms are not important nor insightful. Concerns on the terminologies are addressed in Julie Thompson Klein's "A Taxonomy of Interdisciplinarity" and will be briefly discussed later in this introduction.

2. For a discussion of Campbell's essay and other important essays in Sherif and Sherif's edited book, which includes the Stanley Milgram's essay on the small world experiment, see Jacobs (13-17).

3. Jerry A. Jacobs also defines a discipline as "a form of social organization" that achieves a particular function through an established institution that safeguards its processes for survival and proliferation: "An institutional discipline is a recognized area of study that typically is identified with an academic department and an undergraduate major. An individual with a doctoral degree in a discipline is responsible for mastery of a certain body of knowledge, has contributed to that knowledge base in some way, and may be selected to teach the next generation of students in this field" (28).

4. See Heather Fraser and Nik Taylor's Neoliberalization, Universities and the Public Intellectual for a discussion on how neoliberalism has infiltrated "the very generation and dissemination of knowledge itself" and has "dismantled the idea of a public intellectual" (1). Christopher J. Lucas's "Liberal Education: The Challenge of Consumerism, Careerism, and Commodification" also confronts the challenges of liberal education today, such as radical consumerism, careerism in the academe, and corporate transformation.

5. This is to differentiate this brand of interdisciplinarity also from the ancient Greeks' idea of philosophy as a unified and holistic science (Klein, Interdisciplinarity 19-20) and the works of the Renaissance Humanists in the $14^{\text {th }}$ to the $17^{\text {th }}$ centuries and the writers thereafter including "Francis Bacon, Descartes, the French Encyclopedists, Kant, Hegel, and Comte, [who] each [were] concerned about the fragmentation of knowledge, and each, in his own way, articulated a vision of the unity of knowledge" (Klein, Interdisciplinarity 20-21).

6. According to the $\mathrm{CMO}$, the purpose of general education is to develop intellectual competencies (such as critical, analytical, and creative thinking and multiple forms of expression) and civic capacities (as a member of a community, a nation, and a world) (Article 1). This purpose is achieved through the holistic development of the person that happens in three overlapping realms: the individual, the Filipino society and nation, and the global community (Article 1, Section 1).

7. Although the titles of the core courses may still have a discernible disciplinary bent, the descriptions of the courses in the CMO have opened up their content toward a possible interdisciplinary approach. For example, Science, Technology and Society (Agham, Teknolohiya at Lipunan) includes the ways in which Science 
and Technology are applied that "relate to ethical and political decisions in both the private and public sector[s], and their effects... on society in general" (Appendix A: Brief Explanation of GE Core Courses). Different disciplines may be gleaned from the suggested issues that may be tackled in the course, such as politics and policy work (in climate change and food security); law (in intellectual property rights over patents and discoveries), international relations (in weapons of mass destruction), ethics (in medical ethics and human experimentation), among others.

8. In 2014, the Ateneo Loyola Schools Core Curriculum was also under review in light of the CHED Memorandum Order 20. Making the Ateneo Core Curriculum interdisciplinary was the primary concern while being attendant to the university's Filipino, Catholic, and Jesuit identity. For a discussion on the connection between interdisciplinarity and Jesuit education, see Jose Eos Trinidad's "Interdisciplinarity and Ignatian Spirituality." 


\section{Works Cited}

An Act Enhancing the Basic Education System by Strengthening Its Curriculum and Increasing the Number of Years for Basic Education, Appropriating Funds Therefor and for Other Purposes (Republic Act 10533). Congress of the Philippines. Official Gazette, 15 May 2013, https://www.officialgazette.gov.ph/2013/o5/15/republic-act-no-10533/. Accessed 26 Mar. 2019.

Frodeman, Robert. Sustainable Knowledge: A Theory of Interdisciplinarity. Palgrave Macmillan, 2014.

Implementing Rules and Regulations of the Enhanced Basic Education Act of 2013 (Republic Act No. 10533). Official Gazette, 4 Sept. 2013, https://www.officialgazette.gov. ph/2013/o9/04/irr-republic-act-no-10533/. Accessed 25 Feb. 2019.

General Education Curriculum: Holistic Understandings, Intellectual and Civic Competencies (CHED Memorandum Order No. 20, Series of 2013). Commission on Higher Education, 2013, https://ched.gov.ph/wp-content/uploads/2017/10/CMONo.20-s2013.pdf. Accessed 25 Feb. 2019.

Fraser, Heather, and Nik Taylor. Neoliberalization, Universities and the Public Intellectual: Species, Gender and Class and the Production of Knowledge. Palgrave MacMillan, 2016.

Graff, Harvey J. Undisciplining Knowledge: Interdisciplinarity in the Twentieth Century. Johns Hopkins UP, 2015.

Jacobs, Jerry A. In Defense of Disciplines: Interdisciplinarity and Specialization in the Research University. U of Chicago P, 2013.

Klein, Julie Thompson. Interdisciplinarity: History, Theory, and Practice. Wayne UP, 1990.

--. "A Taxonomy of Interdisciplinarity." The Oxford Handbook of Interdisciplinarity, edited by Robert Frodeman, Julie Thompson Klein, Carl Mitcham, and J. Britt Holbrook, Oxford UP, 2010, pp. 15-30.

Lucas, Christopher J. "Liberal Education: The Challenge of Consumerism, Careerism, and Commodification.” The College Curriculum: A Reader, edited by Joseph L. DeVitis, Peter Lang, 2013, pp. 14-25.

Reyes, Soledad S. "The Interdisciplinary Studies Program." The Romance Mode in Philippine Popular Literature and Other Essays, De La Salle UP, 1991, pp. 113-122.

Sherif, Muzafer, and Carolyn W. Sherif, editors. Interdisciplinary Relationships in the Social Sciences. Aldine Press, 1969.

Trinidad, Jose Eos. "Interdisciplinarity and Ignatian Spirituality." Perspectives in the Arts and Humanities Asia, vol. 7, no. 2, 2017, pp. 1-17.

Weingart, Peter. "A Short History of Knowledge Formations." The Oxford Handbook of Interdisciplinarity, edited by Robert Frodeman, Julie Thompson Klein, Carl Mitcham, and J. Britt Holbrook, Oxford UP, 2010, pp. 3-14. 